\title{
Культурологія
}

UDK $130.2(091)$

\author{
Ovcharuk Olga \\ Doctor of Culture Studies, \\ Associate Professor of \\ the Department of Cultural Studies \\ and Information Communication \\ National Academy of Managerial Staff \\ of Culture and Arts \\ ORCID 0000-0001-5540-3286 \\ OvcharukOlga.19@gmail.com
}

\section{METHODOLOGICAL ASPECTS OF COMPREHENSION OF HUMAN BEING IN THE CULTUROLOGICAL SCIENTIFIC PARADIGM}

The purpose of the work is to substantiate the methodological possibilities of cultural studies as post-nonclassical knowledge in the study of anthropological problems, as well as to identify methodological approaches that correspond to the modern strategy of scientific comprehension of man. The methodology of the research is based on paradigm as a meta-methodology of cultural knowledge, the manifestation of which is discursive variability and interdisciplinary integrity. Structural-functional and phenomenological methods have become key ones to the study of this problem. To change the interpretation of stable semantic constants from positions of post-non-classical knowledge, methods of semiotic analysis and deconstruction are involved. The scientific novelty of the work lies in the definition and disclosure of the essence of methodological approaches, that reveal the specificity of human cognition in the context of the culturological scientific paradigm. Conclusions. Culturological comprehension of a person can be carried out from the standpoint of the following approaches - universalist, individualized and activity-oriented. The approaches identified in the research are an effective methodological tool for cultural science. Synthesis of the proposed approaches makes it possible to identify the relationship between the corresponding levels of development of culture and humanity, culture and man of a certain historical epoch, culture and personality.

Key words: culturological scientific paradigm, man, culture, methodological approaches.

Овчарук Ольга Володимирівна, доктор культурології, доцент, профресор кафедри культурології та інформаційних комунікацій Національної академії керівних кадрів культури і мистецтв

Методологічні аспекти осмислення людини в культурологічній науковій парадигмі

Мета роботи полягає в обґрунтуванні методологічних можливостей культурології як постнекласичного знання в дослідженні антропологічної проблематики, а також виявленні методологічних підходів, що відповідають сучасній стратегії наукового осмислення людини. Методологія дослідження ґрунтується на парадигмальності як метаметодології культурологічного знання, виявом якої $є$ дискурсивна варіативність та міждисциплінарна інтегративність. Ключовими для дослідження даної проблематики стали структурно-функціональний та феноменологічний методи. Для перетрактування стійких смислових констант з позицій постнекласичного знання задіяні методи семіотичного аналізу та деконструкції. Наукова новизна роботи полягає у визначенні та розкритті сутності методологічних підходів, що розкривають специфіку пізнання людини в контексті культурологічної наукової парадигми. Висновки. Культурологічне осмислення людини може здійснюватися з позицій наступних підходів - універсалістського, індивідуалізованого, діяльнісного. Визначені підходи виступають ефективним методологічним інструментарієм культурологічної науки. Синтез запропонованих підходів дозволяє виявити зв'язок між відповідними рівнями розвитку культури та людства, культури та людини певної історичної епохи, культури та особистості.

Ключові слова: культурологічна наукова парадигма, людина, культура, методологічні підходи.

Овчарук Ольга Владимировна, доктор культурологии, дочент, профрессор кафредры культурологии и инфрормационных коммуникаций Национальной академии руководящих кадров культуры и искусств

Методологические аспекты осмысления человека в культурологической научной парадигме

Цель работы заключается в обосновании методологических возможностей культурологии как постнекласичного знания в исследовании антропологической проблематики, а также выявлении методологических подходов, отвечающих современной стратегии научного осмысления человека. Методология исследования основана на парадигмальности как метаметодологии культурологического знания, проявлением которой является дискурсивная вариативность и междисциплинарная интегративность. Ключевыми для исследования данной проблематики стали структурно-функциональный и феноменологический методы. Для изменения трактовки устойчивых смысловых констант с позиций постнеклассического знания задействованы методы семиотического анализа и деконструкции. Научная новизна работы заключается в определении и раскрытии сущности методологических подходов, раскрывающих специфику познания человека в контексте культурологической научной парадигмы. Выводы. Культурологическое осмысление человека может осуществляться с позиций следующих подходов - универсалистского, индивидуализированного, деятельностного. Определенные в исследовании

(C) Ovcharuk O., 2018 
подходы выступают эффективным методологическим инструментарием культурологической науки. Синтез предложенных подходов позволяет выявить связь между соответствующими уровнями развития культуры и человечества, культуры и человека определенной исторической эпохи, культуры и личности.

Ключевые слова: культурологическая научная парадигма, человек, культура, методологические подходы.

Relevance of the research topic. The problem of man and his nature determined the intellectual atmosphere of the twentieth century. As one of the main paradigms of European thinking, it has become a priority not only for philosophy, but also for other areas of humanitarian knowledge. This contributed to the emergence of philosophical-anthropological, cultural-philosophical, cultural-anthropological, psychological and other scientific paradigms. The emergence of the culturological scientific paradigm in the humanitarian space of the 20th century opened new possibilities for understanding the phenomenon of man on the basis of a combination of classical, non-classical and post-non-classical methodologies of cognition. Consequently, for the formation of a new anthropological perspective in the dimensions of the culturological scientific paradigm, it becomes necessary to develop new methodological strategies in human research by justifying appropriate approaches.

Analysis of researches and publications. The problem of a human being in the semantic universe of culture remains a priority for scientific research of modern domestic and foreign scientists. Among them we note studies, in which the human world is comprehended in the interaction of anthropocultural and sociocultural (E. Andros, E. Bystritsky, V. Gorsky, V. Kremen, S. Krymsky, V. Lichkovakh, M. Mardashvili, I. Nadolny, M. Popovich, A. Fed, V. Khamitov and others). In the culturological aspect, labor is important, in which a person appears in the space of culture (S. Bezklubenko, Yu. Bogutskiy, P. Gerchanivska, Yu. Sabadash, G. Chmil, V. Chernets, V. Sheiko, V. Shulgina etc.). The author realizes the cultural essence of man in the paradigms of Modern and Postmodern (A. Belik, E. Bilchenko, M. Brovko, T. Gumenyuk, T. Krivosheya, G. Mednikova, S. Neretina, A. Ogurtsov, V. Rozin, O. Smolina V. Fed, A. Flier and others). A significant number of human-centered studies testify to the urgency of understanding the human phenomenon from the standpoint of various scientific paradigms.

The aim of the work is to substantiate the methodological possibilities of cultural studies as post-nonclassical knowledge in the study of anthropological problems, as well as to identify methodological approaches that correspond to the modern strategy of scientific comprehension of man.

Statement of basic materials. In modern humanities, the development of which occurs on the basis of synergistic, noospheric, planetary thinking, the human problem remains one of the most urgent. The elaboration of culturological approaches to its interpretation makes it necessary to integrate universal philosophical constants, as well as the experience of other scientific knowledge in the problem field of culturology. In this connection, let us turn to the developments of the modern domestic cultural expert P. Gerchanivska [2; 3]. The researcher notes that the semantic field of the term "person" contains a conceptual series, elements of which - "individual", "individuality", "personality", "subject" are determined by certain differential characteristics, but related system relationships and correlate with the surrounding reality and human experience. At the same time, the content of each of the concepts is most fully revealed through the meanings of other semantic components. Without their comprehension it is impossible to understand such sociocultural phenomena as: identity, self-identification of a person, a crisis of identification, subjectivization of a person and the like. As the researcher notes, the essence of the concept "man" is constituted in the dimensions of the dichotomy "culture-individuality", "culture-personality", "cultural subject", however, at the modern post-nonclassical stage of the development of humanitaristics it acquires new ways of thinking [2, p. 79].

Terminological definition of the concept of "individual", "individual" (from Latin Individuum - indivisible), which means "every organism that exists independently" [9, p. 346] allows us to distinguish the following characteristics of a person - biological essence, physical and mental characteristics. The concept of "individuality" indicates the characteristics of the character and mental warehouse, distinguishing one person from another. Individualities are characterized by stable invariants that distinguish it from other species of living nature, among them: consciousness, language, the possibility of knowing objective reality and purposeful action. An important indicator of individuality is a high degree of activity, tension in the work of the inner world of man. The most important of the features that are the conditions for successful activity include creativity, readiness for creative self-realization; the presence of abilities, experience, knowledge, skills; openness to innovation when solving problems; an individually unique system of motives for action and goalsetting, character and temperament.

Despite the fact that the human individuality as a historical phenomenon and a unique combination of spiritual qualities, properties that distinguish one person from another, is manifested only in the Renaissance, the whole subsequent history of mankind has shown the great importance of the very problem of individuality in its projection on the sphere of culture. However, the conceptualization of the problem of "cultureindividuality" cannot take place outside the social and historical aspects. As a social being, a person is constantly in the evolutionary process and personifies the whole spectrum of the world of culture and history. In every culture of the emergence of the individual becomes an objective law and provides for the solution of specific socio-cultural problems. Since the development of the personality is determined by the assimilation 
of the acquired experience, by the transformation of the external conditions included in the sphere of a human being, the whole process of development of individuality reveals its cultural nature and makes it an important and valuable cultural being.

The concept of "personality" reveals" the integrity of individual existence, has the consciousness and self-consciousness of man as a subject of activity and communication, responsible for his actions and actions" [10, 464]. It characterizes the socio-psychological essence of a person, the level of his spirituality and intellectual development under the influence of life in society, upbringing, learning communication and interaction. The concept of "personality" integrates human qualities as homo sapiens, as the creator and bearer of culture and as a social being, which, on the one hand, is the basis of the unity of mankind, on the other the source of its diversity.

As V. Rozin notes, that despite a significant number of different characteristics and definitions of the concepts "personality" and "individual", one can point out among them the most significant and reflected time. First, by a person and an individual, one understands the unique, unique facet of a person. The second characteristic of the personality is given by its socio-cultural dimension. The third characteristic of the personality can be considered the most specific, namely, the personality is what presupposes awareness, selfdetermination, and constitution of one's life [8, 187-188]. Consequently, it is only through going beyond the limits of external social and ideological determination, through self-determination, that a person's ability to be a person becomes possible. Therefore, the personality is formed in the conditions of the formation of a person's own behavior, which requires the appropriate self-organization of the psyche, building up the opposition "I-world", "I-others" and others.

Formation of personality is a complex process of socio-cultural development of man. The natural properties of man, superimposed on the matrix of differentiated sociocultural conditions of human existence, determine the diversity of mankind. The process of human adaptation to the social conditions of a certain community, its cultural values was called socialization. Adapting to the life of society, a person is simultaneously formed as a person, with his inner world and his own individual characteristics. This process is called personalization. Both phenomena are interrelated, however, if in the process of socialization attention is focused on the mastering by the person of the general knowledge, norms, traditions of a certain community, then in personalization it is focused on the individualization of the personality, on its differences from other members of the society [2, 84].

In general, from the standpoint of various spheres of humanitaristics, the concept of "personality" is viewed as an independent entity, separated from culture, within the framework of dialogical attitude, where culture forms the second plane of being of a personality and as a whole with culture, because culture realizes itself in a dialogue with the person, and the personality, in turn, realizes himself in the life of culture. However, for all thinkers, culture and personality appear as independent entities that exist in parallel and define each other.

For culturological comprehension of a person, it becomes important to refer to the category "subject" (Latin Subjectum - what is in the basis). This category is rooted in ancient Greek philosophy and logic, interpreted as the bearer of object-practical activity and cognition; source of activity is directed at the object [9, 797]. Mostly this category was used to determine the material substance or substrate. By the New Time this concept retained the significance of things and only in the philosophy of I. Kant, who introduced the concept of "transcendental subject," the opposition of the subject-object received the content of binarity - the cognizing mind and reality, is cognized. In this case, the transcendental subject, originally intended as the unity of perception and consciousness, begins to be treated not only as a thing, not only as an object and even not only as a carrier of properties. First of all, it acts as a source of activity. Consequently, the concept of the subject acquires a stable connection with spiritual activity - perception, consciousness, thinking - and becomes the designation of the main spiritual substance of man - man as a rational being [2, 81].

In the structure of the cognitive process of the New European philosophy, two main levels are singled out: sensual and rational. The problem of the cognition of the subject is objectified through the projection of the sensory cognition of reality (sensation, perception, representation, etc.), in the process of which the subject interacts directly with the surrounding world, and rational cognition (concept, judgment, inference) that is realized on the basis of abstract thinking and logical reasoning. Unlike sensory cognition, the goal of rational cognition is the reflection of phenomena and processes in the context of their internal connections and regularities, which are comprehended by the rational processing of data of sensory cognition. It is rational knowledge that ensures the existence of such forms of the cognitive process as science and philosophy [7].

In the Postmodern era, which arises in the dimensions of the postmodern classics of deconstruction, the use of the concept of "subject" and its cognition is associated with the notion of its determinism by a number of non-rational and neo-cognitive factors - ideology, language, the unconscious, and the like. The evolution of non-classical philosophy led to the erosion of the subject-object opposition, stating "the death of the subject" - a traditional, stable, uniquely centered and linear, socially determined subject of the Durkheim type. However, Postmodern demonstrates a program orientation toward "resurrecting the subject" and thereby returns to the focus of research analysts problems centered around the phenomena of individuality, personality, but also then of a man as a phenomenon of culture. 
Since there is no absolute subject, the demarcation between the subject and the object is very conditional, as often the person becomes the object of cognition. Consequently, in the process of self-knowledge, the subject becomes an object of study. What is important is that the variability of human consciousness generates the variability of this concept, as a result of which it is transformed in accordance with the fundamental socio-cultural paradigm of time. Consequently, it can be assumed that the essence of the subject varies in the context of the field of human activity, turning into a certain range of modifications, in particular, into a cultural subject or subject of culture.

The formation of a person as a subject of culture is demonstrated by the concepts of V. Bibler [1], as well as philosophical studies of the problems of culture by M. Turovsky [11], V. Lectorsky [6]. In the concept of Bibler, a person becomes a subject of culture, capable of determining his meaningful existence, only in the process of dialogue, on the border of his own and other cultures. At the same time, for the culture itself, there is essentially a being on the border with another beginning of being, the otherness of which is brought to the universality. Therefore, subjectivity in culture and the subjectivity of being is manifested, first of all, in the dialogue of the logician, in understanding and not understanding the other beginning of being, namely, another subject, another culture embodied in its boundary in it as a subject. In the course of his activity, man does not yet become a subject of culture, therefore he does not concentrate in himself the special principle of being. In the goal-setting activity, human subjectivity has not yet been brought to self-determination and universality [1].

For V. Lectorsky and M. Turovsky, the issues of the formation of man as a subject of culture arise from the positions of philosophical comprehension. Thus, when developing a problem of the subject and object, identifying their connection in the process of cognition determines the subject, first of all, as a specific individual, existing in space and time, who is included in a certain culture, has his own biography, and is also in a communicative relationship with other people. Directly inward with respect to an individual, the subject appears as I. In relation to other people, he appears as "the other." In relation to physical things and cultural objects, the subject acts as a source of knowledge and transformation [6].

The key to the concept of M. Turovsky is the question of mastering a person's collective norms and forms of culture, turning into the same goal by which a person opens up the possibility of becoming a subject in relation to culture. It is in the space of culture that it is possible for a person to be a subject, determined by the integrity of all his qualities, properties, mental processes, conscious and unconscious. This is achieved through the individual development of man and is associated with a high level of his personal growth. In the general historical dimension, it is the formation of subjectivity that becomes the determining factor in the anthropogenesis of man in the possibility of its development, including the individual. At the same time, the degree of subjective development in time is determined historically [11].

First of all, the discovery of culturological approaches to the comprehension of man and the substantiation of their specificity can be realized both on the basis of the integration of the elements of the conceptual series of the concept "man", namely, "individual", "individuality", "personality", "subject," and their deconstruction, which allows us to consider each element separately. In general, the systemically organized unity of these elements, designed for a particular type of culture, reveals exactly the image of a man, who is produced and maintained by a particular culture as the person's most acceptable and desired embodiment. Thus, one of the plans "works", aimed at understanding the concept of "man", namely, the general one, proposed in the concept of M. Kagan [4].

At the same time, it is through the connection with culture as a synthesizing characteristic of a person, the mastery of achievements, developed by human self-awareness and subjectivity are acquired to them. A person becomes a subject of culture that represents universal cultural meanings, becomes an expression of individual and collective cultural experience, accumulated by mankind in the process of general cultural development. Consequently, in general terms, a person is a subject of culture and cultural and historical process generates him, changes the content and forms of his life, the creator of culture and at the same time its product, arises as an object of cultural knowledge. This is the key task, for which the disclosure of the universal value-semantic content of the concept of "man" is embodied in various ways by the forms of theoretical reflection, in the images of the artistic worldview, humanistic teachings, material and spiritual monuments of cultural heritage. Thus, this approach can be defined as universalist - aimed at identifying common (universal) and transpersonal meaningful meanings that reveal the essence of a person.

The next approach of culturological understanding of man -individualized can be realized through a special, individual, individual, which manifests itself in such elements as "personality", "individual", "individuality". This dimension allows referring to a person as a unique, unique personality, individuality with his inner world, objective and subjective circumstances of life's collisions and revealing the multifacetedness of the figures of artists as well as the features of their values and ideological positions through the prism of specific historical circumstances. From the standpoint of the presented approach, the processes of the creative formation of personality in culture can be uncovered, the determining factors and their influence on the formation of world outlook, value orientations, life principles and beliefs, moral and aesthetic ideals, and the like are analyzed. Systemic study of various aspects of the life of the personality allows not only to recreate its general picture of the world, but also to comprehend the diversity of human experience and his contribution to a particular culture. At the same time, this way helps to define the basis, structure and directions of the 
creative realization of the individual as a unique person - what fills the "scenario" of his life with the appropriate content and meaning and determines the potential creative possibilities and conditions for their discovery.

Consequently, the combination in the culturological comprehension of man - the universalization and individualization, designed in the specificity of a specific historical and cultural era, makes it possible, on the one hand, to reveal the value-semantic essence of man, which manifests itself in the unique spiritual and cultural experience accumulated by mankind in the process of general cultural development. On the other hand, a person acts as a concrete individual, existing in space and time; he is included in a certain culture, has his own creative biography and is in a communicative relationship with other people. In relation to the individual, the subject acts as the "I", in relation to other people - as "Other". Consequently, through individual, special, individual can be understood the processes of creative formation of personality in culture, a certain role of his contribution to the cultural heritage of mankind.

The next approach - activity, is caused by the culturosocidal essence of man. As the creator of culture, it acquires those specific characteristics that contribute to its cultural (active, objective) selfreproduction, which is realized both spiritually and practically. Among the essential characteristics of a human being as a cultural creature, one can distinguish - the ability to creative activity, oriented toward obtaining reliable knowledge about the world. In the process of creative activity, the subject creates qualitatively new material and spiritual values, realizes himself as a person, transcends the already realized, received, created, embodied, discovered, learned, mastered. Creative activity as the defining essential trait of the subject of culture helps to reveal through his creative actions his personal and individual characteristics. Creativity is the defining feature of the subject of culture. In essence, creativity is a state that characterizes a subject's ability to innovate and demonstrates the degree of his readiness for creative self-realization. The starting point of creativity is the comprehension by the subject of the need for a creative act and its possibilities for its implementation. If creativity is one of the indicators of creative self-realization of a cultural subject, creativity is a necessary component of his life activity.

The orientation of a person as a subject of culture to creative self-realization through various forms and types of cultural development allows not only to actualize culture, to become the creator of new elements of culture, but also to act as a bearer of cultural values and, accordingly, to become an active subject of the cultural process. Attraction to it ensures the formation and development of personality and selfrealization of man in culture. These culturological approaches to understanding a person as a subject of culture allow solving a key question for cultural science, namely, what types of culture are defined and necessary for certain images and concepts of "man", under what circumstances is the transition from some images and concepts of "man" to others [5, 931]. Despite the fact that the answer to this question requires a thorough hermeneutical work, the culturological comprehension of man in the synthesis of the proposed approaches makes it possible to reveal the connection between the corresponding levels of development of culture and humanity, culture and man of a certain historical epoch, culture and personality. Differences in the ontological levels of the universal (general) and individual (especially, individual) in the interaction of culture and man make it possible to identify the causation of the generation of a certain type of culture of one or another person / personality / personality.

Conclusions. Culturological comprehension of a person can be carried out from various positions - a universalist approach aimed at revealing common (universal), transpersonal (meaningful) meanings that are embodied in various ways by forms of theoretical reflection, in images of artistic outlook, humanistic teachings, material and spiritual memories " Hence, man as a subject of culture appears as the spokesman for the cultural experience accumulated by mankind in the process of general cultural development. In the dimensions of an individualized approach, a person in cultural understanding is presented as a concrete individual, existing in space and time; he is included in a certain culture, has his own creative biography and is in a communicative relationship with other people. In relation to the individual, the subject acts as the "I", in relation to other people - as "Other". This approach allows us to disclose the processes of creative development of a particular person in culture, to reveal factors that influence the formation of his worldview, value orientations, life principles and beliefs, moral, aesthetic and spiritual ideals. The activity approach is involved in the process of culturological understanding of man as a subject of culture. At the same time, its essential characteristics are defined - the ability to creative activity, creativity, focusing on creative self-realization.

\section{תimepamypa}

1. Библер В. С. На гранях логики культуры: книга избранных очерков. Москва: Русское феноменологическое общ-во, 1997. $440 \mathrm{c}$.

2. Герчанівська П. Е. Індивід, суб'єкт, особистість, індивідуальність як базові концепти теоретичної культурології: нові підходи і стратегії //Актуальні проблеми історії, теорії та практики художньої культури. Вип. XXXIII. Київ: Міленіум, 2014. С. 78-86.

3. Герчанівська П. Е. Українська специфіка суб'єктивації людини в епоху постмодерну //Людина в сучасному цивілізаційному процесі: фрілософсько-культурологічні та етико-естетичні виміри: монографія /М. М.Бровко та ін.; відп. ред. М. М. Бровко; НМАУ імені П. І. Чайковського. Ніжин: Аспект-Поліграф, 2014. С. 54-74.

4. Каган М. С. Философия культуры. Санкт-Петербург: ТОО ТК «Петрополис», 1996. 416 с. 2007. 1392 c.

5. Культурология: энциклопедия: в 2-х т. Т. 1 / гл. ред. и авт. проекта С. Я. Левит. Москва: РОССПЭН, 
6. Лекторский В. А. Гуманизм как идеал и как реальность // Идеал, утопия и критическая рефлексия. Москва: РОССПЭН, 1996. С. 103-114.

7. Новейший философский словарь. Постмодернизм /гл. науч. ред. и сост. А. А. Грицанов. Минск: Совр. литератор, 2007. 815 c.

8. Розин В. М. Культурология: учебник. Москва: Гардарики, 2003. 462 с

9. Словник іншомовних слів /за ред. акад. АН УРСР О. С.Мельничука. Київ: Головна ред. УРЕ, 1985. 966 c.

10. Теоретическая культурология /А. В. Ахутин и др.; отв. ред. О. К.Румянцев. Москва: Академический проект: Деловая книга; Екатеринбург: РИК, 2005.623 с.

11. Туровский М. Б. Философские основания культурологии /ред. О. К. Румянцев. Москва: РОСПЭН, 1997. 440 c.

\section{References}

1. Bibler V. On the edges of the logic of culture: a book of selected essays. Moscow: Russian phenomenological society, 1997. 440 p.

2. Gerchanivska P. Individual, subject, personality, individuality as the basic concepts of theoretical cultural studies: new approaches and strategies // Current problems of history, theory and practice of artistic culture. XXXIII. Kyiv: Millennium, 2014. pp. 78-86.

3. Gerchanivska P. Ukrainian specificity of human subjectivity in the postmodern era // Man in the modern civilization process: philosophical and cultural and ethical-aesthetic dimensions: monograph. Nizhyn: Aspect-Polygraph, 2014. P. 54-74.

4. Kagan M. Philosophy of Culture. St. Petersburg, 1996. 416 p.

5. Culturology: Encyclopedia: in 2 t. T. 1. Moscow: ROSSPEN, 2007. 1392 p.

6. Lektorsky V. Humanism as an ideal and as a reality // Ideal, utopia and critical reflection. Moscow: ROSSPEN, 1996. p. 103-114.

7. Newest Philosophical Dictionary. Postmodernism. Minsk: Sovr. writer, 2007. 815 p.

8. Rosin V. Culturology: a textbook. Moscow: Gardariki, 2003. 462 p.

9. Dictionary of foreign words / ed. acad. Academy of Sciences of the USSR O. Melnychuk. Kyiv: Main ed. URE, 1985. 966 pp.

10. Theoretical culturology. Moscow: Academic project: Business book; Yekaterinburg: RIK, 2005.623 p.

11. Turovsky M. Philosophical Foundations of Culturology. Moscow: ROSPEN, 1997. 440 p.

Стаття надійшла до редакції 21.04.2018 p. 